\title{
El Nacionalismo Vasco entre la Dictadura de Primo de Rivera y la II República
}

\author{
Cipriano Ramos
}

A la caída de Primo de Rivera (28-1-1930), el rey Alfonso XIII encarga al general Berenguer la formación de un nuevo Gabinete. Su llegada a la presidencia del Gobierno proporciona a los partidos políticos españoles que habian estado proscritos durante el septenio dictatorial o con una existencia legal lánguida la coyuntura política favorable a su propia reorganización.

El nacionalismo vasco llega a este momento orgánicamente dividido en dos ramas, con diferencias ideológicas mínimas; son más de tipo procesal o táctico que doctrinal. Su escisión se habia producido en 1921, dando lugar a dos organizaciones políticas abiertamente enfrentadas: la Comunión Nacionalista Vasca de los Aranzadi (Engracio y Manuel) y Eleizalde, de carácter moderado, estatutista y abierta a la colaboración con el Gobierno de Madrid, y el Partido Nacionalista Vasco, formado por los de "Aberri» y dirigido por Elías Gallastegui, Manuel de Eguileor, José María Errasti y Ceferino de Jemein que dicen defender la doctrina sabiniana en toda su integridad. En consecuencia su actitud es separatista y contraria a todo tipo de colaboración con el Gobierno central que, en terminologia sabiniana, representa al pais dominador y usurpador de los derechos históricos de Euzkadi.

A pesar de estas apreciables diferencias tácticas -las dos ramas nacionalistas persiguen el mismo objetivo final, la autodeterminación-, el nacionalismo vasco llega a 1930 con un gran estancamiento y una cierta uniformidad doctrinal que, en aras de un vehemente deseo de fusión, subrayan sus más destacados ideólogos: « ¿No estamos donde estábamos cuarenta años atrás? ¿No defendemos todo lo que Sabino nos enseñó?»'.

1 Euzkadi, 23-noviembre-1930. "Fe católica y patria vasca». KizkitzA. 
También el articulista de Euzkadi, Bingen, coincidía con esta declaración cuando al defender la conveniencia de buscar la unión hacía referencia a la exigüidad numérica y a la inexistencia de «discrepancias fundamentales». De la imposibilidad de evolucionar nos habla el grupo radical de Aberri en su revista Euzkerea (agosto-1930): «El partido sabiniano no puede evolucionar (...) Nosotros estamos donde estábamos...». Pero a lo largo de 1930 va a hacer su aparición en la escena política del País Vasco un grupo de nacionalistas (unos procedentes de La Comunión, mayoría, y otros del Partido) que pondrá en tela de juicio la eficacia del nacionalismo tradicional y que, en consecuencia, recomendará la necesidad de revisar los principios doctrinales que hasta entonces han inspirado y orientado la conducta de la comunidad nacionalista vasca. Es el grupo revisionista que, a últimos de noviembre, fundará un nuevo partido político, el deAcción Nacionalista Vasca. También en este mes se efectuará la fusión de las dos ramas nacionalistas dando lugar a la formación del nuevo Partido Nacionalista Vasco. Durante este período de tiempo, año puente entre dos regímenes políticos distintos, la actividad del nacionalismo vasco se concretará en tareas de reorganización, en enfrentamientos entre el grupo revisionista y el tradicional y en su diferente actitud ante el advenimiento de la República.

\section{LA DOBLE ESTRATEGIA POLITICA DEL NACIONALISMO VASCO EN 1930}

Ante la oportunidad de reorganización política que la "dictablanda» del general Berenguer ofrece a los partidos politicos, la comunidad nacionalista vasca desarrolla una doble estrategia política: Por una parte la acción negociadora del Partido y de la Comunión en busca de la reunificación y por otra, la maniobra del grupo revisionista concebida para promover un nacionalismo liberal.

José Domingo de Arana, antiguo dirigente de Juventud Vasca de Bilbao, habia cobrado cierto relieve entre los nacionalistas exilados durante su estancia en Acción Nacionalista de Buenos Aires (1927-1928). Al regresar a Bilbao presentó su fórmula de reunificación nacionalista basada en la eliminación de las organizaciones preexistentes, y en quince puntos cuyo eje era «hacer ya una revisión de fuerzas, un recuento de valores, un completo examen del presente frente a los viejos métodos de organización y de lucha. Las viejas organizaciones nacionalistas para estar a tono de las circunstancias presentes han de incorporar nuevas verdades a su ideario y han de eliminar ciertos métodos para adoptar otros más adecuados...» ${ }^{2}$.

${ }^{2}$ Bizkaitarra. 7-enero-1931. «Al pueblo Nacionalista». Citado por Antonio ELoRzA en Ideolo- 
José Ignacio de Arana entendía que para la iniciación del nuevo ideario nacionalista el procedimiento a seguir era el de crear una Asamblea democrática, es decir, la puesta en funcionamiento de un órgano radicalmente distinto de los anteriores:

«A mi parecer, y en armonía con las esencias democráticas que tuvo siempre el país y a las que respondió también nuestro ideario político, una Asamblea amplia, general, en la que a todos oyéramos y en la que todos nos escucharan, sería el método más legítimo, eficaz y adecuado de iniciar la actuación; asamblea que incluso podria tener carácter preparatorio de un Congreso ulterior en el que en definitiva quedasen concretados el ideario y organización de la agrupación política del país, que respondiera a este intangible lema: «Personalidad racial vascas ${ }^{3}$.

Para promover los cambios que todo esto exigía, el grupo revisionista ideó, favorecido por su control de la prensa nacionalista, un complejo procedimiento. Partía éste de un plebiscito abierto a todos los nacionalistas que, de encontrar respuesta afirmativa, vendría a crear un nuevo organismo en sustitución de los dos partidos nacionalistas preexistentes ya que instituía un Comité provisional de veinte miembros (cinco por cada región) que se encargaría de organizar una asamblea en la que «se lleve a efecto una nueva organización de las fuerzas nacionalistas». El diario Euzkadi publicó los extremos de la encuesta o plebiscito a partir del día 15 de junio de $1930 .^{4}$

gia del Nacionalismo Vasco (1876-1937). "De los euskaros a Jagi-Jagi». San Sebastián, edit. Haramburu, 1978. Pág. 412.

${ }^{3}$ Euzkadi. 7-febrero-1930. “La hora de la actuación», José Ignacio de ARANA

${ }_{4}^{4}$ Las preguntas formuladas por Euzkadi eran las siguientes:

$1^{a}$ ¿Cree usted necesario que el Nacionalismo Vasco proceda a una revisión de valores y, en su caso, a un público pronunciamiento que condense sus aspiraciones y programa?

$2^{a}$ ¿Juzga usted conveniente que, paralelamente con ese pronunciamiento, se lleve a efecto una nueva organización de las fuerzas nacionalistas?

$3^{a}$ ¿Estima usted necesario la celebración de una Asamblea de amplio siginificado como medio de que puedan tener realidad los apartados anteriores?

$4^{\text {a }}$ ¿Considera usted oportuna la designación de un Comité provisional integrado por un número igual de representantes de Alaba, Guipuzkoa, Nabarra y Bizkaya, al que se le confiera la labor preparatoria y de organización de la Asamblea?

$5^{\text {a }}$ ¿Cree usted acertado otorgar a ese Comité provisional facultades de ponencia a los efectos de que formule un proyecto en relación con los dos primeros extremos o apartados, sometiéndolo a deliberación de la Asamblea?

$6^{a}$ ¿Que cinco personas de destacado nacionalismo designa usted para formar parte del Comité aludido? 
El tiempo destinado para hacer esta consulta popular se extendía desde el 15 de junio hasta el 20 de julio. Poco antes de expirar el plazo establecido se concedió una prórroga y la fecha límite quedó fijada para el día 28 del mismo mes, con lo que el resultado que en principio debía hacerse público el día 31, festividad de San Ignacio, no se dio a conocer hasta el día 6 de agosto.

El resultado de este plebiscito fue el siguiente:

\begin{tabular}{|c|c|c|}
\hline & Respuestas & $(\%)$ sobre votos emit. \\
\hline 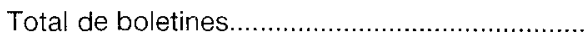 & 3.995 & 100 \\
\hline 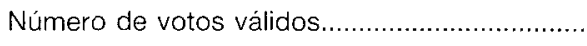 & 2.989 & 74,8 \\
\hline 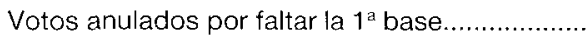 & 117 & 2,9 \\
\hline Votos anulados por faltar a la $6^{a}$ base $\ldots \ldots \ldots \ldots \ldots . . . .$. & 613 & $15,3(25,1 \%)$ \\
\hline Sin contestación & 276 & 6,9 \\
\hline
\end{tabular}

Las cinco primeras preguntas formuladas fueron contestadas de esta forma:

\begin{tabular}{|c|c|c|c|c|}
\hline & Afirmativas & $(\%)$ & Negativas & $(\%)$ \\
\hline $1^{\text {a }}$ revisión de valores............. & 2.691 & 95,2 & 137 & 4,8 \\
\hline 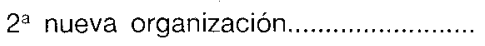 & 2.728 & 96,5 & 99 & 3,5 \\
\hline 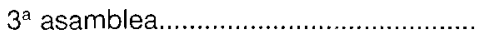 & 2.743 & 97 & 84 & 3 \\
\hline $4^{a}$ Comité & 2.789 & 98,4 & 47 & 1,6 \\
\hline 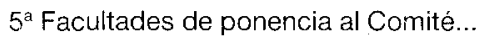 & 2.773 & 98,1 & 54 & 1,9 \\
\hline
\end{tabular}

Los resultados de este plebiscito no tuvieron la misma interpretación en los dos grupos nacionalistas que se van formándo a lo largo de 1930.

Esta encuesta puede verse en Euzkadi. 15 de junio y ss. de 1930. «Erri-Eretxia», Plebiscito. Extremos de la encuesta. 
Para los organizadores del plebiscito el resultado había sido todo un éxito, mientras que para los aberrianos su validez era cuestionable porque no se había llegado a los tres mil votos ${ }^{5}$. El 25,1 por 100 de votos anulados nos induce a pensar que los términos de la encuesta no fueron debidamente entendidos por un amplio sector del nacionalismo ya que afectaba a la cuarta parte de los votantes.

La contestación a la sexta pregunta daría lugar a la formación de un Comité provisional compuesto por veinte miembros, cinco por cada provincia, con atribuciones para organizar la Asamblea y presentar en ella su ponencia sobre el programa y la futura organización del nacionalismo vasco. Los elegidos fueron los siguientes:

Alava: Pablo de Trocóniz, Enrique de Eguren, José $M^{a}$ de Belausteguigoitia, Francisco de Aguirre, José Ramón de Olano

Guipúzcoa: Miguel de Urreta, Avelino de Barriola, José $\mathrm{M}^{\mathrm{a}}$ de Aguirre, José de Eizaguirre, Isaac López Mendizábal.

Navarra: Fortunato de Aguirre, Manuel de Aranzadi, Pablo Archanco, Leopoldo de Garmendia, Francisco de Lorda.

Vizcaya: Ignacio de Rotaeche, Ramón de la Sota y Aburto, José Ignacio de Arana, Luis de Urrengoechea, Ramón de Bikuña.

La inmensa mayoría de los componentes de este Comité provisional era comunionista. Según el profesor José Luis de la Granja, sólo el alavés Francisco de Aguirre era aberriano ${ }^{6}$. Su discrepancia sobre la política a seguir por el nacionalismo vasco los dividió en dos grupos, aconsejando unos la reunificación bajo el lema JEL (Jaungoikua eta Lagi-zarra: Dios y Ley vieja), y otros la escisión que diera lugar a la creación de un partido nacionalista aconfesional: Acción Nacionalista Vasca.

Paralelamente a la actividad del grupo reformista se desarrolla la de los dirigentes del Partido y la Comunión que piensan en la reunificación de ambas ramas bajo la bandera del aranismo. Los primeros contactos negociadores comienzan a últimos de febrero de 1930. Euzkadi, órgano de prensa de La Comunión hace pública una nota señalando que las autoridades del PNV han manifestado sinceros deseos de fusión:

\footnotetext{
5 Euzkerea. 15-agosto-1930. "Después de un plebiscito".

- José Luis de la Granja: Nacionalismo y II República en el País Vasco. Centro de Investigaciones Sociológicas. Madrid. 687 págs., pág. 40.
} 
"Las autoridades del PNV nos comunican que, con fecha de hoy, 25 de febrero, se dirigen por escrito a la Comunión Nacionalista proponiendo las bases de unidad de pensamiento y de acción que, a juicio de los proponentes deben ser aceptadas por ambas partes, con carácter fundamental, para llegar a la unión firme y duradera de todos los nacionalistas vascos en una sola colectividad politica organizada, deseo ferviente -hoy más que nunca- de cuantos vascos militan en las distintas Agrupaciones denominadas nacionalistas" "

A partir de estos momentos el entusiasmo por la unión se hace cada vez más patente, y de manera muy especial, en los grupos de jóvenes montañeros que durante el septenio de forzosa inacción política supieron mantener viva la llama nacionalista por medio de numerosas excursiones programadas a distintos lugares de la topografía vasca. El Euzkadi de los primeros días de marzo publica varias cartas y artículos de mendigoxales que propugnan la unión bajo el ideal sabiniano. Muchos de estos montañeros se habían formado y modelado al calor e impulsos de Juventud Vasca de Bilbao, centro nacionalista del que había sido presidente el carismático y radical abertzale Elías de Gallastegui. Asi manifestaba su entusiasmo por la unión el grupo de mendigoxales «Irrintzi»:

"....Vengamos risueñamente esperanzados a la unión doctrinal, con la mirada fija en el porvenir y salvación del pueblo vasco, abrazados a la misma idea de redención todos los que, como nosotros, sueñen en una patria, única e indivisible, y como nosotros también sientan vibrar sus almas y agitar sus pechos...”.

Otro grupo de idénticas caracteristicas al de «lrrintzi» publicaba en el mismo diario unos sentimientos análogos, al mismo tiempo que expresaba sus puntos de vista en lo tocante al procedimiento que se debía seguir de cara a la unificación. Al mismo tiempo hacía profesión de fe en su credo integramente sabiniano:

".....Frente único anhelamos, pero, entiéndase bien, con una doctrina, unas normas, y una bandera! Aquéllas con las que caminábamos todos juntos en una fe hasta el año 1915, en que se produjo la primera escisión, la que culminó en la Asamblea de Donostia el año 1920. Aquel recuerdo lo llevamos clavado con agudo dolor; pero si se nos siguiese planteando aquel dilema, abrazariamos ese dolor hasta la muerte, como una cruz de redención, antes de negar del credo integramente sabiniano o convertir en silencio que el procedimiento político anule o desmienta esa doctrina que es nuestra vida y a la cual nos debemos inquebrantablemente".

7 Euzkadi. 25-febrero-1930. «Por la unión de los nacionalistas vascos».

8 Euzkadi. 1-marzo-1930. "La unión de los nacionalistas. Los del grupo Irrintzi». 
Vemos, pues, a la juventud nacionalista vasca convertida en paladín defensor del nacionalismo tradicional. El grupo al que hemos hecho referencia no suscribia la idea de acudir todos juntos a una Asamblea para fijar en ella el ideario a seguir en una actuación futura. Esto sería tanto como reconocer que hasta la fecha no se había tenido un ideario. Tampoco estaba de acuerdo con la afirmación de que para la unión sólo bastaba con aceptar el principio de la nacionalidad vasca y que el resto pudiera discutirse en un Batzarre nacional: "La doctrina sabiniana no se puede discutir en ningún Batzarre. Escrita está con claridad tan meridiana que no admite interpretaciones ${ }^{9}$.

De este entusiasmo juvenil participaban, como por contagio, relevantes figuras del Partido y de la Comunión. Manuel de Aranzadi, por ejemplo, a impulsos de la natural euforia que despierta la efervescencia política del momento, propugna la unión, «sacrificando, si fuera preciso, hasta particulares convicciones, y desde luego, personalismos, agravios y recuerdos amargos. Todo, todo lo que sea necesario, hasta la anulación propia.... ${ }^{10}$. Esta espontánea declaración del ex diputado nacionalista navarro, más hecha con el corazón que con la mente, no podia ser compartida por quienes proponían que la unión debía hacerse con cautela, que el PNV debía presentar unas bases y que debian ser analizadas con detención por la Comunión: «(...) ¿Para qué esto? -se refiere a la corazonada de Aranzadi-. ¿Para poner a discusión en el Batzarre lo que antes se había aceptado ciegamente? (...) Porque hoy es solamente el corazón el que puede llevarnos a esa unión a todo trance; pero mañana cada pensamiento reclamará su órbita de expansión, y se vería desdichadamente -y con peores consecuencias tal vez- la inutilidad de los esfuerzos hechos contra un criterio razonable ${ }^{11}$.

Tres razones principalmente debieron mover a los dirigentes nacionalistas a buscar la unión: La debilidad organizativa y su consecuente ineficacia política probada en las últimas elecciones de abril y junio de 1923, la favorable coyuntura política del momento y, por último, la inexistencia de notables diferencias ideológicas.

Durante el mes de marzo, Comunión y Partido someten sus respectivas bases de unidad a la discusión de sus agrupaciones, patentizándose en las del PNV «el deseo de unión a base de mantener la pureza integral de la doctrina nacionalista sabiniana ${ }^{12}$. A primeros de abril ambos parti-

\footnotetext{
${ }^{9}$ Euzkadi. 9-marzo-1930. «Ante la unión de los nacionalistas vascos. Un grupo de mendigoxales".

10 Euzkadi. 2-marzo-1930. «La unión». IKASLE.

11 Ibidem.

12 Euzkadi, 4-abril-1930. Nota del PNV.
} 
dos designan las comisiones encargadas de llevar a cabo la negociación. Por parte de La Comunión fueron designados Francisco de Basterrechea, Severo de Altube y Antonio de Araluce. Por el Partido, los Sres. Baltasar de Amézaga, Ceferino de Jemein y Manuel de Eguileor. Las reuniones comenzaron hacia el 8 de abril y concluyeron el 12 de junio. Entre estas fechas se tomaron los siguientes acuerdos: $1^{\circ}$ Doctrina nacionalista sabiniana. $2^{\circ}$ Nombre de PNV para la nueva organización. $3^{\circ}$ Organización del año 1914. Hubo, sin embargo, algunos puntos de divergencia: La composición interna de Euzkadi -centralismo unitario de la Comunión o estructura confederal de Aberri-, la escuela euzkeralógica sabiniana y el tema de la subordinación de la prensa nacionalista a las autoridades del nuevo partido. Como el acuerdo no fue total, las negociaciones prosiguieron hasta el momento mismo de la unión.

La doble estrategia seguida por el nacionalismo vasco durante la primavera y el verano de 1930 quedó resuelta entre septiembre y noviembre de ese mismo año. Designado el Comité provisional de los veinte por medio del plebiscito, los promotores del mismo tratan de darle un contenido práctico a partir de septiembre. Así, por iniciativa de José Ignacio de Arana, el Consejo de Administración de Euzkadi convoca al Comité provisional de los veinte a una reunión en Euzko-Etxea de San Sebastián para el día 14. Mediante esta reunión se pretendía poner en práctica cuanto se había planeado conseguir con el plebiscito: Preparar una Asamblea y redactar la ponencia que después sería discutida en ella ${ }^{13}$.

Los aberrianos ya se habian apercibido de que la cuestión del plebiscito habia sido una maniobra política ideada por sus promotores para darle al nacionalismo una base doctrinal y una organización distintas. De ahí que cuestionaran su validez y negaran representación del nacionalismo a los miembros del Comité provisional de los veinte. Este celebró su reunión el día 14, como estaba previsto, pero, en vista de que las autoridades del PNV presionaban para que en una declaración, el Comité sólo reconociera representación a las organizaciones preexistentes del Partido y de La Comunión, acordó, por unanimidad, otorgarles su reconocimiento y redactar la ponencia que después sería debatida en la Asamblea General. Mediante este reconocimiento el Comité dejaba la tarea de reorganizar el nacionalismo en manos del PNV y de la CNV, autolimitándose las facultades que le habia conferido el plebiscito.

El día 26 de octubre de 1930 el Comité provisional de los veinte celebra una nueva reunión con el fin de discutir y aprobar la ponencia que se

${ }^{13}$ Euzkadi. 7, 11, 14, 23-septiembre-1930. 
ha de presentar en la Asamblea General. A la reunión asisten 14 de los 20 que componen el Comité. La nota característica de esta reunión es la profunda división que se detecta en el Comité. Esta división se concreta en la presentación de dos ponencias completamente distintas. La ponencia mayoritaria cuenta con el apoyo de 10 miembros del Comité (los navarros: Aguirre, Aranzadi, Archanco, Garmendia y Lorda; Ios alaveses: Trocóniz, R. de Olano y Belausteguigoitia; y los vizcaínos: Urrengoechea y Arana). El texto de esta ponencia sirvió de base para la elaboración del Manifiesto de San Andrés ${ }^{14}$. La ponencia minoritaria es defendida por los cuatro restantes; son los guipuzcoanos: Barriola, Eizaguirre, Urreta y López Mendizábal. Según el Acta de la sesión «Guipuzkoa opina que el programa nacionalista no necesita nuevas orientaciones y que lo preciso es unir a las dos ramas nacionalistas en una sola organización ${ }^{15}$. En consecuencia apoya la doctrina contenida en JEL y rechaza todo tipo de reforma. Las bases de actuación contenidas en la ponencia mayoritaria serán después las que orienten la conducta de ANV. La ponencia señalaba como norma fundamental de actuación «no combatir y en lo posible ayudar a los partidos vascos que afirmen como base de sus respectivas ideologías la personalidad propia y diferencial del país".

\section{Estas eran las bases de actuación señaladas en la ponencia:}

\section{Con respecto al País Vasco:}

A) Laborando por la reconstrucción y fusión del euzkera y de todas las características de la raza y nacionalidad vasca, desarrollando e intensificando su propia cultura, afirmando y estrechando los lazos de unión entre sus componentes; haciendo, en una palabra, que cada vez aparezca más radiante y esplendorosa el alma de la colectividad nacional.

B) Laborando para que en la vida interna del País Vasco las entidades administrativas que lo rigen se entiendan fraternalmente en régimen de trato recíproco de excepción y privilegios al amparo de los preceptos de orden legal que facilitan incluso la formación de mancomunidades.

\footnotetext{
${ }^{14}$ El llamado Manifiesto de San Andrés con el que oficialmente nace ANV viene a ser una ampliación y en algunos puntos una copia literal de la ponencia mayoritaria aprobada por el Comité provisional de los veinte en su asamblea de 26-octubre-1930. El texto de la ponencia puede verse en Euzkadi. 28-octubre-1930. El de manifiesto en La Tarde y El Liberal. 3-ciciembre-1930.

${ }^{15}$ La ponencia minoritaria de los guipuzcoanos estuvo apoyada también, según José Luis de la Granja, por J. Ma Aguirre, F. Aguirre y Rotaeche. (Ausentes).
} 
C) Favoreciendo el que en las diferentes zonas de Euzkadi, y aun en sus distintos municipios, se vayan resolviendo los problemas particularistas que afectan a la posesión de la tierra, a las relaciones de capital y trabajo, etcétera, en armonía con el principio racial de la personalidad nacional vasca y con los postulados que informan los movimientos de carácter social en otros pueblos y colectividades.

D) Colaborando con todo partido vasco que persiga la restauración integra de los conculcados derechos del país o que propugne una constitución confederada o federal del Estado español, desde luego menos unitarista que la actual.

\section{Con respecto a España:}

Colaborando con los partidos que a juicio de Acción Nacionalista, según sus órganos legítimos de expresión, proclamen o reconozcan los derechos de las colectividades nacionales a disponer de sus destinos; que tiendan más eficazmente a una estructuración del Estado español confederada, federal o siquiera menos unitarista que la actual; que mejor garanticen los derechos individuales; que mejor aseguren el orden jurídico incompatible con todo sistema de dictadura, arbitrariedad o poder personal; que resuelvan com mayor espíritu de equidad y justicia los problemas sociales; que reduzcan al Ejército a la esfera de su propia función, con derogación de la ley de jurisdicciones, y, en fin, que propugnen un régimen jurídico-político más en armonía con los imperativos democráticos bajo los que ha vivido y quiere vivir nuestro pais ${ }^{16}$.

El mismo dia 26 de octubre La Comunión celebra dos asambleas regionales, las de Vizcaya y Guipúzcoa. En la asamblea regional de Vizcaya se discuten los tres problemas que siguen sin solución: La escuela euskeralógica, la configuración política de Euzkadi y la dirección política de la prensa nacionalista.

En la asamblea regional de Guipúzcoa se renueva el GBB, quedando elegido como presidente Avelino Barriola y como vocales, los Sres. José $M^{a}$ de Aguirre y Martín de Gallastegui. Celebradas las asambleas regionales, La Comunión convoca su Asamblea General para el 1 de noviembre. En ella se aprueba el acta de unión del día 29 de abril y se leen las dos ponencias que no llegan a discutirse por afectar a una doctrina que ya se había aprobado. Lo más notable de esta asamblea es la intervención de

${ }^{16}$ Euzkadi. 28-octubre-1930. «Acta de la reunión celebrada en Donostia el domingo, 26 de los corrientes". 
Manuel Aranzadi que declara que él había firmado la ponencia mayoritaria por si no se llegaba a la unión, pero que ante ésta «sacrificaba sus opiniones personales". La postura de Aranzadi, personalidad relevante dentro del nacionalismo vasco, debió arrastrar a un buen número de navarros, con lo que la ponencia mayoritaria fracasó.

EI PNV ya había celebrado su Asamblea General el día 28 de septiembre, en Bilbao. En ella se ratifica en la idea de que la unión de los nacionalista debe llevarse a cabo siguiendo los acuerdos tomados por su comisión negociadora (Baltasar de Amézaga, Ceferino de Jemein y Manuel de Eguileor): Doctrina nacionalista sabiniana, nombre de PNV para la nueva organización y organización del año 1914.

Como vemos, las dificultades para lograr la fusión de los nacionalistas vascos se encuentran en la propia división interna de los miembros del Comité provisional de los veinte. Dada su pertenencia mayoritaria a La Comunión, los mayores obstáculos para sellar esta unión se encuentran en este sector nacionalista, no en el PNV, ya que desde un principio y con absoluta claridad ha propuesto la unión bajo el lema JEL.

\section{LA ASAMBLEA DE REUNIFICACION DE VERGARA (16 de noviembre de 1930)}

El domingo, día 16 de noviembre de 1930, se reúnen en el batzoki de Vergara los delegados del Partido y de la Comunión con el fin de buscar solución a sus últimos problemas y sellar su unión. La presidencia queda encomendada; por común acuerdo, al recientemente designado como presidente del GBB, Sr. Barriola. A lo largo de la mañana prosiguen las conversaciones en torno al problema de la dirección política de la prensa nacionalista, sin que se llegue a un acuerdo. La diferencia principal estaba en que unos opinaban que los directores de prensa debían ser nombrados por el EBB y otros, por los Consejos Regionales. Con el problema de la prensa nacionalista todavía por medio, las representaciones de los dos partidos celebran asambleas por separado. En la de La Comunión el grupo revisionista intenta que se acepte la ponencia del plebiscito como base de unión de los nacionalistas. Al no conseguirlo anuncia su escisión. En esta asamblea se da lectura a un manifiesto de los estudiantes vascos de $\mathrm{Ma}-$ drid que está dirigido a las autoridades nacionalistas. En él se contienen las dos ideas fundamentales que explican el nacimiento de ANV ${ }^{17}$.

\footnotetext{
17 Entre los que firmaban el manifiesto se encontraban dos fundadores de ANV, Pedro
} 
Por la tarde se llegó a un acuerdo sobre la cuestión de la Prensa. Se encontró la solución en la aplicación de una fórmula transaccional que confería competencias a los Consejos Regionales y al Nacional: Los Consejos Regionales se encargarían de la dirección en su respectivo territorio y el Nacional quedaría como guardián supremo de la ortodoxia del Partido, interviniendo en el nombramiento de los directores de los periódicos, que eran propuestos por aquéllos ${ }^{18}$. Superada esta dificultad, la unión quedó sellada.

En esta asamblea estuvieron representadas 124 Juntas Municipales, distribuidas de esta forma: 53 de Vizcaya, 45 de Guipúzcoa, 25 de Navarra y una sola de Alava. Asistieron más de 150 delegados, de los cuales, 85 vizcaínos, 59 guipuzcoanos, 26 navarros y unos 10 alaveses ${ }^{19}$. Estos datos son una buena prueba de la irregular implantación del nacionalismo vasco en las provincias vascas: Desarrollo rápido en Vizcaya y Guipúzcoa y muy escaso y lento en Alava y Navarra.

\section{REORGANIZACION DEL NACIONALISMO VASCO}

Sellada la unión de las dos ramas nacionalistas con el lema JEL como bandera, todas las autoridades municipales, regionales y nacionales preexistentes cesaron de sus cargos, procediéndose, de inmediato, a la formación de unas Comisiones Regionales interinas, cuya misión principal sería la de reorganizar la nueva agrupación política. Cada una de ellas asumiría

Maria Irujo y Luis $\mathrm{M}^{2}$ Eleizalde. A este escrito hacia alusión Kizkitza en un artículo publicado en Euzkadi. 25-noviembre-1930, titulado "La unión por Sabino de Arana”: “(...) Leyóse en la reunión de la mañana un escrito dirigido a la misma por un grupo de jóvenes universitarios vascos de Madrid. Inspirados por la inexperiencia y el afán de apresurar la marcha, con innegable buena fe y patriotismo pedian a la Asamblea esos jóvenes universitarios la mutilación del lema sabiniano arrancando el carácter confesional del nacionalismo".

18 José Luis de la Granja, op. cit., págs. 49-50.

19 Euzkadi. 18-noviembre-1930. No estando reconstruidas aún las Juntas municipales de Alava, salvo en la capital, la representación alavesa fue muy reducida. Estuvo formada por los Sres. Antonio Vinós, Francisco de Madinabeitia, Santiago de Pagaldai, Pablo de Trocóniz, Lucio de Andoain, Aguirre, Diez y alguno más; en total unos 10 representantes. A la asamblea asistieron las más relevantes personalidades del nacionalismo vasco: Los ex diputados a Cortes Ignacio Rotaeche, Manuel de Aranzadi y José de Eizaguirre. Los ex diputados provinciales José Ignacio de Arana, Luis de Urrengoechea, Julián de Arrien, Federico de Zavala, Miguel de Urreta, Manuel de Eguileor, José Manuel de Ispizua, Antonio de Araluce, Gorgonio de Renteria, Jesús R. Villachica, Ubaldo de Segura y alguno más. Además de éstos, asistieron otros tan conocidos como Engracio Aranzadi, Policarpo Barrena, Enrique de Orueta, Francisco de Arregui, José Antonio de Aguirre, Eduardo Urrutia, José $\mathrm{M}^{\mathrm{a}}$ de Belausteguigoitia, Francisco de Basterrechea, Baltasar de Amézola, Jesús $M^{a}$ de Leizaola... etc. 
la autoridad suprema en su respectiva provincia hasta el nombramiento de las autoridades definitivas. Estas comisiones quedaron formadas por dos miembros, uno del Partido y otro de La Comunión:

Alava: Antonio Vinós (CNV) y Francisco de Aguirre (PNV), ambos de Gazteiz (Vitoria).

Guipúzcoa: José $\mathrm{M}^{\mathrm{a}}$ de Aguirre (CNV), de Tolosa y Domingo Arruti (PNV), de Zarauz.

Navarra: Santiago Cunchillos (CNV) y Luciano de Armendáriz (PNV), los dos de Iruña.

Vizcaya: Sandalio Tejada (CNV) y Francisco de Arregui (PNV), de Bilbao.

La tarea de reorganizar el nuevo PNV quedó encomendada a estas Comisiones Regionales. Al tratarse de una nueva organización política, el punto de partida arrancaba de la nueva afiliación de sus militantes. De ahí que su más importante y urgente labor consistiera en reorganizar la afiliación de todos los núcleos nacionalistas. Para ello requirieron la colaboración de las últimas Juntas Municipales y la de los miembros directivos de batzokis y Juventudes. Estas autoridades nacionalistas locales deberían reunirse en cada pueblo para designar entre todos una Comisión interina que asumiera la autoridad del nacionalismo en su respectivo municipio. Después se procedería al nombramiento definitivo de la Junta Municipal, célula básica de la organización jelkide ${ }^{20}$.

Para la formación de la Comisión municipal interina bastaba con el entendimiento de «dos patriotas fervientes" que pidieran hojas de afiliación a la correspondiente Comisión Regional interina y les hicieran «llenar a los nacionalistas de los pueblos". Para la constitución de la Junta municipal definitiva bastaba con que en una reunión de diez afiliados se eligiera a sus tres miembros: Presidente, tesorero y secretario ${ }^{21}$. Constituida esta junta, se elegía el apoderado o representante que debía acudir a las asambleas regionales y nacionales. El proceso de reorganización fue rápido en Vizcaya y Guipúzcoa. En Alava y Navarra, en cambio, fue lento y de escasa importancia. Vizcaya pudo celebrar su Asamblea Regional el día 21 de diciembre de 1930 con la asistencia de 53 apoderados. En esta asamblea, y en votación secreta, se eligió el Consejo Regional de Vizcaya (BBB) inte-

20 Euzkadi. 19, 20, 21 y siguientes-noviembre-1930. La Comisión Regional interina a todos los nacionalistas de Bizkaya, Guipuzkoa y Alava.

21 Euzkadi. 9-enero-1930. Proclama del Partido nacionalista guipuzkoano. 
grado por cinco miembros ${ }^{22}$. La Asamblea Regional de Guipúzcoa, también convocada para este día, no llegó a celebrarse. Se demoró la convocatoria para el 1 de febrero de 1931 y con esta fecha quedó constituido el Consejo Regional (GBB). Quedó constituido también por cinco miembros $^{23}$. Los Consejos Regionales de Alava y Navarra quedaron constituidos en marzo, siendo elegido Angel Fajardo como presidente del primero y Manuel Aranzadi del segundo. El 7 de abril quedó constituido provisionalmente en Vergara el Consejo Nacional (EBB), con representantes de los Consejos Regionales de Alava, Guipúzcoa y Vizcaya, quedando reservado un puesto vacante para el de Navarra (NBB) ${ }^{24}$. La constitución definitiva tuvo lugar en Zumárraga el 6 de mayo de 1931.

A pesar de la escisión que se produce en la comunidad nacionalista vasca con el nacimiento de ANV, es, sin embargo, el año 1930 el período de más rápida expansión organizativa de la historia del PNV. A finales de año habia más de 200 batzokis en funcionamiento ${ }^{25}$. La reaparición de Emakume Abertzale Batza vendrá un poco más tarde. EL 25 de junio de 1931 quedará constituída su nueva Junta Directiva. A partir de este momento alcanzó un desarrollo casi tan grande como el de los batzokis en $1930^{26}$. A esta organización se sumaroriotras complementarias de niños como las «Poxpoliñas», «Gaztetxus» y «Neskames».

\section{ACCION NACIONALISTA VASCA}

En 1930 todos los nacionalistas vascos coinciden en la conveniencia de crear un nuevo partido mediante la fusión de las dos ramas nacionalistas preexistentes. La dificultad radica en que se intenta conseguirlo mediante dos concepciones distintas y enfrentadas: Un grupo mayoritario

22 Euzkadi. 23-diciembre-1930. La Asamblea Regional de Bizkaya. Los elegidos fueron Ios siguientes: Ramón de Vicuña (presidente), Amancio Urriolabeitia (vicepresidente), Antonio de Araluce (secretario), Manuel Eguileor (tesorero) Manuel Robles Aranguiz (vocal).

${ }^{23}$ Euzkadi. 3-febrero-1931. El GBB quedó constituido por los siguientes miembros: Policarpo Barrena (presidente), José $\mathrm{M}^{\mathrm{a}}$ de Aguirre (secretario), Florencio de Olaciregui y los vocales Avelino de Barriola y Martín de Gallastegui.

${ }^{24}$ Euzkadi. 8-abril-1931. EUZKADI-BURU-BATZAR. Constitución provisional. Formado por los siguientes miembros: Ramón de Vicuña, Amancio de Urriolabeitia, Manuel de Eguileor, Antonio de Araluce, Policarpo Barrena.

${ }^{25}$ Georges Stanley PAYNE: El Nacionalismo Vasco. De sus origenes a ETA. Dopesa. BarceIona, 1974, pág. 167.

José Antonio de AGuirRe: Entre la libertad y la revolución. 1930-1935. Pág. 164.

${ }^{26}$ Enciclopedia General Ilustrada del País Vasco. Editorial Auñamendi. Estornés Lasa Hnos. San Sebastián. 
propone la fusión bajo el lema del nacionalismo tradicional y otro, bajo un nacionalismo moderno, liberal, democrático. Con este objeto se llega a la Asamblea de Vergara. Los dos grupos buscan la unión bajo idearios y organizaciones distintas. El grupo revisionista, que es minoritario, propone, sin éxito, que la ponencia mayoritaria del plebiscito sea la base de unión de los nacionalistas. Al no conseguirlo, anuncia su escisión y piensa en un nuevo partido; es el de Acción Nacionalista Vasca. Es la primera vez que de forma estable aparece en al escena política vasca un partido nacionalista de izquierdas ${ }^{27}$. Pero aunque su escisión se produce oficialmente en la Asamblea de Vergara, la formación de este nuevo partido se va gestando a lo largo de 1930. Desde la campaña del plebiscito hasta la escisión van quedando gradualmente al descubierto los propósitos del grupo reformista. ANV nace oficialmente el 30 de noviembre de 1930 con la publicación del llamado Manifiesto de San Andrés ${ }^{28}$.

La maniobra política ideada por este grupo comienza con el plebiscito, prosigue con la elaboración de la ponencia y concluye con la escisión y creación de un nuevo partido. Un amplio sector de La Comunión no llegó a descubrir durante la campaña plebiscitaria las verdaderas intenciones de sus promotores. Destacados polemistas jelkides, como "Leonardo", así lo confirman a últimos de noviembre. Confiesa que no podian «sospechar entonces que bajo estas palabras tan elásticas -se refiere a la campaña del plebiscito- se escondiera una preparación meticulosa de todo cuanto luego ha venido apareciendo $»^{29}$.

Pocos días después de la Asamblea de Vergara el grupo disidente nombró su Comité provisional que quedó formado por los once primeros firmantes del Manifiesto de San Andrés. Todos ellos habian pertenecido a organizaciones nacionalistas vascas: A La Comunión los Sres. Anacleto de Ortueta, José Ignacio de Arana, José Domingo de Arana, Julián Arrien, Luis de Urrengoechea, Claudio Ibáñez Aldecoa, José Ramón Basterra, José $M^{a}$ Belausteguigoitia y José Manuel Ispizua. A Juventud Vasca de Baracaldo, Antonio Villanueva y a Aberri, Marcos Ayo Llona ${ }^{30}$.

27 Pueden considerarse como precursores lejanos de ANV los dos partidos creados por Francisco de Ulacía en 1910 y 1911: Partido Nacionalista Vasco Liberal y Partido Republicano Nacionalista Vasco. Como antecesor más inmediato, el Partido Nacional Vasco de Baracaldo (1922-1923). Todos estos partidos tuvieron una existencia muy efimera.

${ }^{28}$ Se llama asi por coincidir con la festividad del dia.

${ }^{29}$ Euzkadi. 5-diciembre-1930. «Cómo y cuando se separó el grupo de Acción Nacionalista Vasca». Leonardo.

30 José Luis de la GRANJA, op. cit., pág. 55-56. El Liberal. 3-diciembre-1930: «El manifiesto de Acción Nacionalista Vasca». 
El Comité fundador de ANV está formado por vizcaínos que trabajan en Bilbao o en las márgenes de al ría y que proceden, en su mayoria, de la pequeña burguesía ${ }^{31}$.

Para defender la ponencia del plebiscito ANV editó a primeros de noviembre un semanario titulado Nacionalista que siguió apareciendo hasta el 20 de marzo de 1931. Cuatro días después aparece Acción Vasca sustituyendo a aquél. ANV utiliza estos medios informativos para defender y dar a conocer su ideario y para censurar la conducta reaccionaria del nuevo partido jelkide. Los fundadores de ANV, aun siendo de idéntica extracción político-social que muchos de los dirigentes del PNV eran menos conservadores y se preocupaban más por los problemas sociales.

\section{DIVERGENCIAS IDEOLOGICAS Y POLITICAS ENTRE PNV Y ANV}

Las mayores diferencias se encuentran en lo político y en lo religioso. Concretamente en la confesionalidad del PNV y en la apertura de ANV hacia otros partidos. Defensor ardiente de la confesionalidad en el PNV es Engracio Aranzadi, quien publica en el diario Euzkadi de los últimos días de noviembre de 1930 toda una serie de artículos dirigidos a probar la indisolubilidad de los principios de patria vasca y fe católica ${ }^{32}$. El ideólogo comunionista que defiende con firmeza el catolicismo del PNV como algo de lo que no puede prescindir tolera la existencia de un nacionalismo liberal, aunque éste no se puede mantener invocando a Sabino, como es lógico: «(...) No es noble, no es leal, no es justo, sino intolerable en absoluto el valerse de la obra de Sabino y de los discípulos de Sabino para alzar aquí lo que Sabino y nosotros entendemos que es pernicioso en alto grado a las almas». En otra parte de este artículo dice: «(..) Nos oponemos a que organicen y nutran las filas laicistas con católicos; a que vengan a nosotros para arrebatarnos nuestros soldados. Nos oponemos a que echen sus redes en nuestras aguas, para llevarse lo que es nuestro, no suyo,, 33 .

En el número 9 de Nacionalista se elogiaba la separación de la Iglesia y el Estado que se estaba llevando a cabo en las Repúblicas americanas.

31 José Luis de la GranJa, op. cit., pág. 55-56. El Liberal. 3-diciembre-1930: «El manifiesto de Acción Nacionalista Vasca».

${ }^{32}$ Euzkadi. 20-noviembre-1930. «Sólo por Dios...», día 21: «Religión y patriotismo vasco». Día 23: «Fe católica y Patria Vasca». Día 25: «La unión por Sabino de Arana». Día 27: «Nacionalismo Vasco Liberal». KIZKITZA.

${ }^{33}$ Euzkadi. 27-noviembre-1930. 
Nacionalista valoraba positivamente este proceso de separación de los dos poderes, afirmando que "con ello se asegura la independencia absoluta de la Iglesia y la no injerencia de ésta en las funciones de Estado". De esto extraía "Leonardo", pseudónimo de Federico de Zabala, la conclusión de que este mismo orden de cosas se deseaba para el País Vasco. Refutaba la postura de ANV presentando la separación de poderes como una doctrina contraria al catolicismo y que ya habia sido condenada por los Romanos Pontífices: «(...) Mas en los negocios en que intervienen las dos potestades, es muy conforme a la naturaleza de las cosas y a la Providencia de Dios no la separación, ni mucho menos el conflicto entre una y otra, sino la concordia, y ésta conforme a las causas próximas e inmediatas que dieron origen a entrambas Sociedades ${ }^{34}$.

La calurosa defensa que hace "Leonardo" de la confesionalidad del PNV y de la no separación de la Iglesia y el Estado provoca la adopción de un tono mucho más agresivo en las columnas del semanario Nacionalista. Irónicamente manifestaba éste que había hecho una labor de selección "penosísima» sacrificando todas aquellas naskaldijak que no encajaban en el tono y estilo que se ha propuesto guardar en su labor política» ${ }^{35}$.

Los principales fundadores de ANV eran católicos practicantes, pero eran partidarios de mezclar la religión con la política. Euzkadi los acusó de anticlericales por las declaraciones que se hacian en Nacionalista. En su afán de censurar la subordinación del PNV a la Iglesia llegaba, a veces, demasiado lejos. En la página $4^{\mathrm{a}}$ del número 9 de Nacionalista se publica un artículo de Juan Artelu en el que se hace una afirmación realmente injuriosa: Dice que la Iglesia es una "organización material y humana que en la tierra mantiene -o dice mantener- la doctrina de Cristo, institución organizada en potencia terrenal, aliada de otras potencias nefastas, del capitalismo, de la injusticia, de la inmoralidad poderosa e hipócrita...”

Si ANV criticaba la subordinación incondicional del PNV a la Iglesia, éste censuraba duramente las pruebas de anticlericalismo que se publicaban en el órgano oficioso de prensa de la nueva organización política disidente, así como su cada vez más patente inclinación hacia los partidos

${ }^{34}$ Euzkadi. 11-enero-1931. «Disipando confusiones. Eleizalde por JEL». Leonardo. La cita la toma de la Encíclica de León XIII, «Inmortali Dei».

35 Euzkadi. 22-enero-1931. “A falta de razones, insultos». Leonardo. De una extensa lista copiamos algunos: «Imaginación fanática», "sumisión fanática a todo el que lleve sotana", «alguno pensaba que se habia ido de fraile», "personaje funesto para el nacionalismo», "pequeño Maquiavelo del nuevo partido", «en período de franca regresión mental», «argucia de mala fe con lágrimas de cocodrilo"... «Leonardo" se preguntaba: ¿Cómo serán las rechazadas cuando las seleccionadas son... como ha visto el lector?. 
de izquierda. Nacionalista defendia que su unión con republicanos y socialistas no era un obstáculo para que los fundadores fuesen sinceros católi$\cos$. No duda «Leonardo» de que esto fuese así, pero los ataques que se hacian «a la Iglesia y sus ministros» resultaban, para él más que sospechosos.

Ya a últimos de noviembre de 1930, los dirigentes jelkides veían en ANV una progresiva inclinación hacia las izquierdas. Ni en la ponencia ni el Manifiesto se habla expresamente de su orientación izquierdista, pero en su semanario sí se hace cierta alusión a ella cuando habla de la «actual coyuntura en que hay varios particos que nos ofrecen una autonomía en forma federal» ( $n^{\circ} 1,2^{a}$ pág.). En el $n^{\circ} 4 ; 1^{\text {a }}$ pág. añade: «Por lo visto, estamos obligados a rechazar lo que según se dice por ahí "el diablo nos quiere regalar"». Esto le olía a «Leonardo", a Prieto y a República federal. Lo que a finales del 30 era una suposición, por otra parte, bien fundada, será una realidad palpable en los primeros meses de 1931 cuando ANV forme parte del bloque antimonárquico en las elecciones municipales del 12 de abril.

Entre el PNV y ANV existen también notables diferencias de carácter político, tanto en lo que respecta a la colaboración con los partidos políticos que laboran por el advenimiento de la República como por su diferente concepción de la futura configuración política de Euzkadi. Se trata de la acíualización de la vieja polémica que enfrenta el confederalismo de Aberri con el centralismo unitario de La Comunión.

Cuando ANV se une al bloque antimonárquico en las elecciones municipales del 12 de abril piensa en que la implantación de una República federal en España seria conveniente para que el País Vasco pudiera recuperar sus históricas libertades. En consecuencia, se une a aquellos partidos que mayor entusiasmo demuestran por la autonomía de los territorios históricos. El PNV, en cambio, en coherencia con el ideal sabiniano que rechaza la colaboración, acude en solitario. Su acentuado derechismo le impide colaborar en la implantación de un régimen liberal y laico que, en definitiva, sería un peligro para su integrismo religioso.

ANV acepta los principios de la democracia liberal (aconfesionalidad derechos individuales, tolerancia...), mientras que el PNV los rechaza en favor de una democracia vasca, foral y católica.

En los primeros meses de 1931, el PNV hace reiteradas manifestaciones públicas acerca de su indiferencia por el régimen político que habria en España después de los comicios municipales del 1.2 de abril. La cues- 
tión de Monarquia o República era para los jelkides un pleito ajeno del que poco podría beneficiarse Euzkadi:

“(...) Yo he recordado varias veces que don Ramón Ortiz de Zárate, ilustre hombre público alavés, decia respecto a la guerra carlista que era pleito a resolver allende el Ebro, y que los vascos debian ser extraños a él, pues a fin de cuentas dábales lo mismo Isabel o Carlos en el trono de Madrid. ¿No vuelve a tener esto actualidad, cuando lo que hoy se disputa es monarquía o república?. Ni aun siendo ésta federal nos va nada a nosotros en ello. Ni la perpetuidad de lo existente, ni el cambio, han de suponer un mejoramiento, un paso siquiera en el reconocimiento de nuestros derechos" ${ }^{36}$.

La configuración política de Euzkadi es otra cuestión en que los dos nuevos partidos no están de acuerdo. La mayoría de los miembros del Comité provisional de ANV proceden de La Comunión. (De los 11 miembros que forman el Comité, 9 pertenecen a ella, uno a Aberri y otro a Juventud Vasca de Baracaldo). En vísperas del golpe militar del 13 de septiembre de 1923, el tema de la organización política de Euzkadi es motivo de fuertes polémicas entre La Comunión y Aberri. Las autoridades de aquélla señalaron el dia 1 de abril, festividad de la Pascua de Resurrección, como la fecha idónea para celebrar el Día de la Patria. Con la celebración de los actos programados para ese día se reafirmarían en la defensa de su centralismo unitario frente al confederalismo propugnado por Aberri. Toda la campaña propagandística se llevó a cabo bajo el slogan PRO INTEGRIDAD VASCA. Le dieron el nombre de Aberri Orobatasun Eguna y bien podría ser considerado como un claro antecedente del primer Aberri Eguna de la Historia del Nacionalismo Vasco celebrado en marzo de 1932. En 1930 el tema vuelve a ponerse de actualidad y constituirá una notabla divergencia ideológica entre el nuevo PNV y ANV durante la II República española. El pensamiento político de ANV con respecto a Euzkadi queda bien reflejado en los artículos publicados en su nuevo órgano oficial de prensa a lo largo de 1933. Veamos qué opinión le merecían a Juan de Zuazo los términos confederación y federación en Tierra Vasca:

«(...) Fijémonos en dos conceptos que hoy se confunden y sin embargo tan distintos: Federación y Confederación. Confederación, es el término primitivo de la constitución de pueblos afines; es la primera ocurrencia que sigue a la tribu. Siendo éstas incapaces para lograr objetivos comunes y convenientes a todas ellas, se reúnen para dar a un organismo superior, la autoridad y la fuerza para que pueda cumplirlos.

${ }^{36}$ Euzkadi. 4-febrero-1931. "Los jóvenes vascos ante la política". F. Jabier de LANDABURU. 


\section{Cipriano Ramos}

La soberanía reside abajo, el poder reside abajo; son los núcleos dispersos los que ceden algo asi, para que a esa organización, no superior, sino, en términos, se pudiera decir, distinta a ellos, cumpla unos fines meramente policiacos.

(...) El término siguiente en la perfección política de los pueblos, es la Federación. La Federación es el Estado constituido, en el que, los poderes que reciben sus partes son como delegación de un Poder superior. Es decir, no es éste quien recibe en cesión ciertos servicios. Son las partes las que reciben del Estado superior, por delegación de éste, aquellas facultades que se juzgan necesarias para que puedan estas partes servir at interés general.

Este estado intermedio de constitución de una nacionalidad, cuyas partes se hallan bastante diferenciadas, cabe perfectamente en aquellos países en donde hay diferencias apreciables en unas y otras «Regiones».

¿Corresponde a Euzkadi este estado intermedio federativo?.

$¿$ ¿Hay en realidad tal diferencia entre unas y otras regiones, que deba hacerse una constitución federativa?

La cuestión es de gran importancia. Y en este sentido no pondría obstáculos Acción Nacionalista Vasca; si la palabra federación se entendiera en su verdadero sentido. Es decir, en el sentido de que una sola nacionalidad, da, cede poderes a unas regiones, sin que éstas, en ningún caso, tengan el derecho ni puedan separarse de la federación.

Vamos más adelante en nuestro razonamiento y llegamos ya al término que es realmente la postura, no de uniformidad, sino de unidad; aquella organización nacional, en donde se reconozca un Estado, en donde no exista más que un poder superior. Un Estado, en donde, desde arriba, vengan aquellas concesiones de poder a las partes del mismo; en donde se otorgue una autonomía administrativa amplisima a los Municipios, base natural de la nacionalidad.

Este Estado vasco, con esta forma de actuar, es el que nosotros concebimos. Un Estado en el que no exista esa libertad de separación del mismo. Un Estado en el que la autonomia municipal no sea un mito. tangible.

$Y$ sobre todo, un Estado en donde la libertad individual, sea una realidad

Unidad en la Patria vasca; libertad nacional y libertad individual. Base racional de una actuación nacionalista de tipo modernos ${ }^{37}$.

Otra notable diferencia que separa a ANV del PNV es que en ambos nacionalismos se advierte una filosofía distinta en lo que respecta al trato que ha de darse a la población foránea, al elemento extraño al país. AVN defiende un nacionalismo aperturista que ro pide apellidos vascos, sino «la voluntad del ciudadano dispuesta a servir a un pueblo que llamamos

37 Tierra Vasca. 4-junio-1933. "Unidad nacional. Euskadi no es más que una». Juan de ZuAzo. Puede verse también 5-agosto-1933: «Un ejemplo de separatismo intravasco». A:«(..) Un dia y otro venimos machacando sobre este tema. Nosotros tenemos la seguridad que en el campo jelista, el 95 por 100 de las personas responsables, piensan como nosotros en ese asuntom. 
Euzkadi». El PNV, en cambio, en defensa de un nacionalismo tradicional, exige apellidos vascos, pureza de sangre. El partido disidente celebra que vayan desapareciendo los tradicionales y peyorativos epítetos de «extraño», «maketo», «vocinglero», «chulapo» y «raza de Lucifer».

Con esta diferencia de conducta para con los extraños al país se definen dos tipos de nacionalismo: Uno universal y voluntarista, el que defiende ANV y otro, racista, de pureza de sangre y de apellidos vascos, el del PNV. Como paladín defensor de este nacionalismo tradicional, racista, combate "Kizkitza» desde las columnas de Euzkadi la ofensiva antirracista de Tierra Vasca y el apoyo que le prestan La Voz de Guipúzcoa de San Sebastián y El Liberal de Bilbao ${ }^{38}$.

Para cerrar este epigrafe, nada me ha parecido más conciso y a la vez clarificador que la descripción que hace un humorista vasco, profundo conocedor de la doctrina jelista, de la ideologia que orienta la conducta de estos dos partidos políticos:

\section{Principios esenciales de doctrina jelista}

1. Pureza de raza o limpia sangre.

2. Catolicismo.

3. Sumisión y subordinación de lo político a lo religioso.

4. Separatismo intravasco.

5. Supeditación del proletariado al servicio de la plutocracia; del trabajo al capital.

6. Supeditación del hombre a la idea de Dios y Patria.

7. Alimentación puramente histórica.

\section{Principios esenciales de doctrina nacional}

1. Vascos de raza o de afección.

2. Aconfesionalidad.

3. Independencia político-religiosa, o sea, separación de la Iglesia del Estado.

4. Unidad vasca.

5. Lucha libre del proletariado a un régimen más justo y humano.

6. Supeditación del hombre a la idea de Patria y libertad.

7. Alimentación integral. Voluntad.

${ }^{38}$ La polémica en torno al nacionalismo racista del PNV y el nacionalismo universal y voluntarista de ANV se refleja en sus respectivos órganos de prensa Euzkadi y Tierra Vasca de enero a marzo de 1933. Defendiendo el nacionalismo de ANV escriben Juan de Zuazo, Felipe Olabarri y Arbelaiz. Por el PNV, Kizkitza. Ver Tierra Vasca. 29-enero-1933 y 1, 2, 8, 26-febrero-1933. Euzkadi. 23 y 24-febrero-1933. 
8. Partido de clase fraccionado.

9. Idioma e himnos bizkainos.

10. Dogmatismo político-religioso y social. PATRIA LIBRE CON HOMBRES ESCLAVOS.
8. Partido de causa nacional.

9. Idioma e himnos nacionales.

10. Independencia absoluta político-religioso y social. PATRIA LIBRE CON HOMBRES LIBRES $^{39}$.

\section{LA LUCHA POR EL CONTROL DE EUZKADI}

Escindida la comunidad nacionalista vasca a raíz de la Asamblea de Vergara en dos nuevas agrupaciones políticas, Partido y Acción entrarán a último del 30 y primeros meses del 31; en una dialéctica de críticas y descalificaciones recíprocas que son, por una parte, producto lógico del mantenimiento de idearios y programas distintos y enfrentados y, por otra, un auténtico choque de intereses. Cada partido intenta aumentar su esfera de influencia dentro del campo nacionalista y para ello pretende hacerse con el control exclusivo de la prensa nacionalista, con el control de Euzkadi. Este diario había sido el órgano oficial de prensa de la CNV durante la Dictadura de Primo de Rivera. Al constituirse las dos nuevas organizaciones políticas con elementos provenientes de aquélla, las dos creen tener derecho a la posesión del diario. De esta forma Euzkadi se convierte en auténtica manzana de discordia para las dos ramas nacionalistas. La lucha por el control del periódico levanta una serie de enfrentamientos verbales que llevan a sus promotores al terreno de los insultos personales. El grado de agresividad es tal que, probablemente, los meses de febrero a abril de 1931 sean los de máxima tensión en las relaciones del PNV con ANV. Es lo que se conoce con el nombre de «Pleito de Euzkadi».

La discusión sobre el control de Euzkadi se va incubando a lo largo de 1930; pero es a partir de la escisión de ANV cuando el pleito se recrudece con mayor fuerza. Los antecedentes del pleito los encontramos en los años de la Dictadura. Por entonces el diario Euzkadi atravesaba una mala situación económica, lo que llevó a los dirigentes nacionalistas a considerar que la única solución estaba en poner al frente de su administración a una persona enérgica y con grandes poderes de gestión. La persona designada por el EBB fue Anacleto de Ortueta, relevante nacionalista de La Comunión, a quien se le entregó la mayor parte del capital, 55

39 Tierra Vasca. 25-abril-1933. «Política confusionista. Salvando principios doctrinales». S. Manterola. 
acciones de EUZKO-PIZKUNDIA y TIPOGRAFICA GENERAL; las 45 restantes quedaron en manos de Gustavo Scheifler y Javier Gortázar ${ }^{40}$. La entrega de las acciónes no implicaba posesión de las mismas sino tenencia como meros depositarios. La tenencia mayoritaria confería el control de las empresas editoras, el cual recaía, por ello, en Anacleto de Ortueta. Al terminar la Dictadura, éste consiguió sanear la posición económica del diario. A finales de 1929, siendo Rotaeche presidente del EBB, reclamó las acciones a los tres consejeros. Scheifler y Gortázar las devolvieron, pero Ortueta las retuvo cuestionando que Rotaeche fuera ya la suprema autoridad del nacionalismo vasco.

En marzo de 1930, el Consejo de Administración de EUZKO-PIZKUNDIA se amplió a diez miembros. Presidido por José Ignacio de Arana, contaba con tres miembros que más tarde serán cofundadores de ANV y con siete que se irán al nuevo partido reunificado en Vergara ${ }^{41}$. La formación de este nuevo Consejo de Administración supuso el fin del control de EP por Ortueta. Siguió manteniéndolo, no obstante, en TG ya que seguía ejerciendo la presidencia del Consejo del que formaban parte su yerno Felipe Goiri y Julián Arrien.

Como recordaba el Sr. Rotaeche, La Comunión Nacionalista Vasca entregó al Sr. Ortueta las citadas 55 acciones no en calidad de poseedor sino como depositario. Este asi lo había reconocido explícitamente en diversos documentos, actas de Consejos y Juntas de las Sociedades. Para justificar su negativa a devolverlas recurría al subterfugio de negar la representación del nacionalismo vasco al $\mathrm{Sr}$. Rotaeche y a quienes se las entregaron en 1925. Entonces reconocía su representación; ahora, en cambio, que se las reclaman, no.: (...) Existe duda o dificultad de conocer quiénes ostentan su auténtica representación, cuya elección se reserva el depositario $"{ }^{42}$. Estos argumentos del Sr. Ortueta carecían de consistencia para el presidente del EBB porque la totalidad de las personas que le habian confiado el depósito de las acciones habian permanecido fieles a la ideología y programa que entonces tenía el nacionalismo vasco, siendo, por el contrario el Sr. Ortueta quien se había apartado de esta doctrina creando otro partido de ideología y credo distintos. En consecuencia, no le asiste al Sr. Ortueta "derecho alguno a negar calidad para recibir el

\footnotetext{
40 José Luis de la Granja, op. cit, págs. 84 y ss. Ver Euzkadi y La Tarde meses de febrero y marzo de 1931.

${ }^{41}$ Euzkadi. 1-febrero-1931. "El documento que prometíamos ayer». Al nuevo PNV pertenecerán los reelegidos Scheifler y Villachica, más José Antonio de Aguirre, Jesús $\mathrm{M}^{a}$ de Leizaola, Gorgonio de Rentería, Pedro de Elgoibar y Marino Gamboa. De ANV serán José Ignacio de Arana, José Domingo de Arana y Arrien.

${ }^{42}$ Euzkadi. 31-enero-1931. «Dice el señor Rotaeche».
} 
depósito a quienes están en igual lugar y actitud que cuando le hicieron la entrega».

A través del control que Ortueta seguia teniendo en TG, Acción Nacionalista Vasca expulsó a Euzkadi de esta imprenta a últimos de enero de 1931. José Ignacio de Arana como presidente de Tipográfica General decretó la suspensión de contrato entre TG y EP, lo cual supuso que Euzkadi dejara de tirarse en los talleres de TG. Durante los últimos dias de enero y primeros de febrero Euzkadi se editó en los talleres que le prestó ABERRI ${ }^{43}$. Los enfrentamientos alcanzaron tal grado de virulencia que los talleres de TG tuvieron que ser custodiados por las fuerzas del orden. El PNV hizo responsable al Sr. Ortueta de la prohibición de que el diario Euzkadi fuera editado en los talleres de TG.

Durante los meses de febrero y marzo el PNV recibió innumerables muestras de solidaridad y apoyo por parte de personalidades relevantes dentro del mundo de la política y de las finanzas, adhesiones que gustosa y cuidadosamente publicó en las columnas de Euzkadi. Emprendió una agresiva campaña contra el Sr. Ortueta y contra ANV, mientras que éstos se vieron obligados a adoptar una postura meramente defensiva; quizá porque reconocían que la razón estaba de parte del PNV ${ }^{44}$. Para éste, la única solución al conflicto pasaba por la devolución incondicional de las 55 acciones a sus legítimos propietarios. ANV era partidaria de compartir con el PNV los medios editoriales. Este, en cambio, con la fuerza moral que le daba la convicción de ser su único y auténtico dueño, en nigún momento manifestó la idea de cómpartirlos. De ahí que su actitud fuera siempre mucho más agresiva que la de Acción. El diario La Tarde decía que no había que entender este pleito como una cuestión de propiedad de las Empresas editoras de la Prensa nacionalista pues en todo momento ANV «tiene declarado y reconocido que esa propiedad pertenece por esencia y potencia al nacionalismo vasco, A TODO, ABSOLUTAMENTE TODO EL NACIONALISMO VASCO " ${ }^{45}$. Para el PNV no existía la menor duda acerca de la titularidad de la Prensa nacionalista. Entre 1926 y 1929 el Sr. Ortueta había reconocido siempre al EBB y a las personas que le representaban:

"Cuando el EBB le reclan'ó las 55 acciones fue cuando empezó a hablar del "Nacionalismo" como término difuso y vago y no del EBB como organismo con-

43 José Luis GranJa, op. cit., pág. 88. Los números de Euzkadi de los últimos dias de enero y primeros de febrero tienen unos caracteres tipográficos distintos.

${ }^{44}$ La prensa local bilbaína se ocupa ampliamente del tema. Euzkadi le dedica páginas enteras. Puede consultarse también La Tarde, 2, 4 y 6-febrero-1931.

45 La Tarde. 7-febrero-1931. «Un manifiesto de Acción Nacionalista Vasca». 
creto y preciso al que siempre se había sometido. Entonces, cuando las acciones le son discutidas, y JAMAS ANTES, es cuando el cerebro del señor Ortueta acude a la gran invención, el truco máximo, la ficción ingente: «EL NACIONALISMO, TODO EL NACIONALISMO, EL NACIONALISMO INTEGRAL» ${ }^{46}$.

A finales de marzo de 1931 se suavizan las tensiones y Euzkadi cede en la campaña de críticas y censuras contra el Sr. Ortueta y ANV. La acción judicial y la negociación política sustituyen a la campaña de acusaciones. El PNV lleva el caso a los Tribunas de Justicia, y en tal situación ANV se niega a negociar todo tipo de entendimiento electoral con el PNV mientras éste no retire las demandas judiciales ${ }^{47}$.

ANV, aprovechando la utilización exclusiva de los talleres de TG, decide crear su propio diario. Le dará el nombre de Acción Vasca y tendrá una existencia muy efímera. El primer núrmero aparece el dia 24 de marzo manifestando en él su voluntad de entendimiento con el PNV. Estas manifestaciones fueron comentadas con una fuerte dosis de ironia por el partido jelkide:

«(...) Corazón de nuestro corazón nos llama con frase que nos ha hecho llorar de emoción. ¿Cómo acertaremos a corresponder debidamente?

Sangre de nuestra sangre, carne de nuestra carne, huesos de nuestros huesos, entretelas de nuestras entretelas es para nosotros Acción Vasca. Más aún. Linotipias de nuestras linotipias, rotativa de nuestra rotativa, cuentas corrientes de nuestras cuentas corrientes, finca de nuestra finca, es para nosotros Acción Vasca. Mejor dicho, "Cincuenta y cinco Acciones Vascas", que es como en realidad se titula, aún cuando haya evitado modestamente el plural» ${ }^{48}$.

La realización de un acto de fuerza inesperado por parte de algunos jelkides cambió radicalmente la marcha de los acontecimientos. El 7 de abril de 1931 se celebró una Junta General de accionistas de TG. A ella acudieron aeneuvistas y jelkides armados. Un afiliado del partido jelista logró sustraer a José Domingo de Arana 20 acciones de las 55 procedentes de Ortueta, con lo que desde este momento el PNV se convirtió en poseedor mayoritario y ANV en minoritario. Este mismo dia se nombró un nuevo Consejo de Administración. Quedó formado por los jelkides Gortázar, Gárate y Elgoibar, quedando, de esta forma, el control de TG en manos del PNV. El diario Euzkadi volvió a editarse en sus talleres y Acción

46 Euzkadi. 21-febrero-1931. "Comparando fechas".

47 Nacionalista. 20-marzo-1931.

${ }^{48}$ Euzkadi. 25-marzo-1931. «Corazón de nuestro corazón». 
Vasca espulsada ${ }^{49}$. El pleito continuó estando sub judice hasta abril de 1933, ya que el hecho inesperado al que nos hemos referido no fue la solución del conflicto. ANV, que nunca habia querido apropiarse de la totalidad de los talleres sino compartirlos con el PNV, a partir de este momento comenzó a decir que le habian robado veinte acciones y que las máquinas donde se editaban los periódicos eran suyas.

A los pocos días de proclamarse la República en España llegó a Bilbao el nuevo gobernador de Vizcaya. Era el alavés José Martínez de Aragón, uno de los gobernadores de mejor memoria para el PNV debido a su "acendrado vasquismo". A través de una carta dirigida al Sr. Martínez de Aragón por el Sr. Ortueta, pudo el PNV saber que ANV habia pedido la intervención del gobernador en el pleito. Había solicitado su intervención por mediación del Bloque Antimonárquico. Se le pedía al nuevo gobernador que por "Un acto de fuerza contra Euzkadi, se apoderase de él, y lo entregara a manos del señor Ortueta. ${ }^{50}$. En esta misma carta el Sr. Ortueta le comunica al gobernador que ANV «en justa correspondencia a su loable intervención, se considera obligada, «(...) a relevarle de toda ulterior preocupación derivada de la gestión que en nuestro nombre realizó cerca de usted el bloque antimonárquico...”.

Según las declaraciones hechas por el gobernador de Vizcaya, la intervenición requerida no había sido hecha por el bloque en pleno, sino por algunos dirigentes de ANV:

«(...) Cuando llegué a Bilbao me encontré con que los elementos directivos de Acción Nacionalista Vasca esperaban mi llegada para que intervíniese en el pleito que sostenía con el Partido Nacionalista Vasco, intervención concretada a un acto de fuerza, alegando que las máquinas donde se editaban los periódicos eran de su propiedad y que les habian robado veinte acciones ${ }^{51}$.

El Sr. Martínez de Aragón no aceptó este tipo de intervención porque como él dijo, esta forma de actuar repugnaba «con sus sentimientos y con el cargo que venia a desempeñar». Sin embargo, se creyó obligado a inter-

49 José Luis Granja, op. cit., págs. 92-93.

50 Euzkadi. 28-abril-1931. "Una carta de ANV. El juego, a descubierto". En esta carta, el Comité ejecutivo de ANV dice, entre otras cosas: $1^{\circ}$ Que, desposeida de los medios editoriales del nacionalismo vasco, requirió la intervención del bloque antimonárquico como medio a quo de reparar tan injusto atropello... $2^{\circ}$ Que el bloque, percatado de la procedencia de nuestra demanda, realizó cerca de usted la gestión interesada para que hiciera valer los medios ejecutivos que a su autoridad competen, reponiendo a Acción Nacionalista Vasca en aquella posesión de que habia sido despojada".

51 Euzkadi. 29-abril-1931. "Sobre las gestiones de tregua. Resumiendo la historia». 
venir por medio de la persuasión. Trató de que los dos partidos depusieran su actitud; al no conseguirlo, como se diera cuenta de que se podía quebrantar la firmeza del bloque antidinástico, amenazó con la dimisión. Siguió en su puesto de gobernador de Vizcaya y propuso una vía negociadora a los dos partidos consistente en una tregua que, corregida con alguna enmienda por ANV, fue aceptada por ésta, pero rechazada por el PNV. La intención conciliadora del Sr. Martínez de Aragón pedía la colaboración de las dos ramas nacionalistas en la tarea de presentar a las Cortes una petición acorde sobre las reivindicaciones del pueblo vasco. Como ya se ha dicho, el PNV rechazó la propuesta del gobernador y, a su vez, presentó una nueva fórmula a ANV. Mediante esta fórmula buscaba la acción conjunta, la creación de un frente comưn para la defensa del Estatuto ante las Constituyentes, pero, incomprensiblemente, dejaba sin resolver el principal problema, el de la Prensa nacionalista ${ }^{52}$. La negativa por parte de ANV llegó bajo la forma de una carta firmada por el Sr. Ortueta con fecha 27 de abril de 1937 y estaba dirigida al solidario Manuel Robles Aranguiz:

\footnotetext{
«(...) Y como la finalidad primordial que se descubre en la fórmula que usted nos envía es la de combatir los fundamentos apuntados de nuestra incorporación al bloque y nuestra actuación dentro del mismo, que deseamos continuar con la mayor lealtad, por entender que es el único camino franco para llegar a la eficacia de aquel derecho de autodeterminación, es obvio concluir que forzosamente tenemos que desechar en absoluto la toma en consideración de su fórmula, que, por otra parte, desvia el verdadero problema que el acendrado vasquismo del señor Gobernador civil sometió, en la entrevista a que usted alude, a las representaciones de las dos ramas del nacionalismo, y que respondia exclusivamente al deseo de hallar una fórmula de armisticio temporal para que ambas pudieran utilizar equitativamente, durante un plazo determinado, los medios de difusión y razonada defensa de sus respectivas ideologías ${ }^{53}$.
}

El Sr. Ortueta demandó judicialmente a los jelkides por la sustracción de las 20 acciones, pero sin éxito, ya que en abril de 1933 terminó el pleito a favor de los demandados. En cuanto a la creación de un frente común para defender el Estatuto vasco ante las Constituyentes, tampoco hubo entendimiento, ya que ANV prefirió seguir unida al bloque antidinástico. Como se ha visto, entre el nacionalismo tradicional del nuevo PNV y el liberal de ANV, había profundas diferencias ideológicas que imposibilitaban la unión. A los que apuntaban pequeñas diferencias les decía «lkasle»:

"(...) Jaungoikua es en el Nacionalismo de los Arana-Goiri el principio fundamental y el remate venturoso de toda su doctrina patriótica. Para ANV, ni es

52 La fórmula presentada por el PNV a ANV puede verse en Euzkadi, 28 y 29-abril-1931.

${ }^{53}$ Euzkadi. lbidem. 
fundamental ni es fin; es una idea extraña a su nacionalismo, con la que éste nada tiene que ver. ANV ignora simplemente a Jaungoikua. ¿Esto es una diferencia de poca monta, o un abismo infranqueable de separación? (...) Ni el pensamiento religioso, ni el patriótico tradicional, ni el de la Confederación; nada de la concepción nacionalista de los Arana-Goiri es compartido francamente por ANV ${ }^{54}$.

\section{EL PNV ANTE EL PACTO DE SAN SEBASTIAN Y LA II REPUBLICA}

Se conoce como Pacto de San Sebastián el acuerdo firmado en el círculo republicano de San Sebastián (17-agosto-1930) por el que los asistentes decidieron constituir un Comité Revolucionario para encauzar las actuaciones en favor del advenimiento de la República. En aquella reunión, Miguel Maura y Alcalá Zamora, en nombre de la derecha liberal republicana, aseguraron la incorporación de sectores moderados y católicos de las clases medias; Prieto y Fernando de los Ríos, que asistieron sólo a título personal, lograrian después la participación del partido socialista y un amplio sector de la clase obrera; a su vez, Carrasco y Formiguera, de Acció Catalana, Mallol, de Acció Republicana de Catalunya, y Aiguadé, de Estat Català, asi como Casares Quiroga, de la Federación Republicana Gallega, aportaron la adhesión del catalanismo (que obtuvo la promesa de un estatuto autónomo) y del galleguismo; por último, Lerroux y Azaña, por Alianza Republicana, y Marcelino Domingo, Albornoz y Angel Galarza, por el partido radical-socialista, representaron las principales fuerzas republicanas. Estuvieron también presentes, pero a título personal, Sánchez Román y Ortega y Gasset. Como vemos, a la reunión no asistió ningún nacionalista vasco, ni a título personal ni en representación del partido.

En la reunión de Donostia se habló de la República Federal y del reconocimiento de las regiones españolas a tener un Estatuto de autonomía:

«(...) La República proclamada reconocerá a todas las regiones que lo reclamen el derecho a elaborar su propio Estatuto, pero como proposición o ponencia, que será sometida a las Cortes Constituyentes para su discusión, aprobación, enmienda o rechazo. Todas las regiones formando la nación federal España y sus relaciones entre si y con el Estado federal, acordadas por las Cortes Constituyentes ${ }^{55}$.

54 Euzkadi. 6-mayo-1931. «Unión, no. Colaboración, sí. Acción inmediata». IKASLE.

55 Una carta de Alejandro Lerroux dirigida a Angel Rizo. En ella explica lo que fue el Pacto de San Sebastian. Euzkadi, 5-agosto-1931, la toma de Informaciones. 
El derecho del País Vasco a tener un Estatuto de autonomía quedaba, pues, reconocido por los firmantes del pacto aunque no hubiera asistido a la reunión ninguna representación del país. El Sr. Aiguadé y Miró, que fue uno de los asistentes, refiere brevemente este reconocimiento:

«(...) Arreglada la cuestión catalana, creo que fue Casares Quiroga, el delegado de Galicia, quien pidió para Galicia y Vasconia un trato semejante, y hasta fue una velada acusación de egoismo a los catalanes por no haber hablado más que en favor suyo.

(...) Sin discusión se acordó conceder a Galicia y Vasconia un régimen semejante al de Cataluña. (...) Prieto temía que los nacionalistas vascos, donde predominaban los reaccionarios, diesen un Estatuto manifiestamente contrario al espíritu izquierdista» $\$$.

Después de implantarse la República en España, el jefe del socialismo vizcaino, Indalecio Prieto, acusó reiteradas veces a los nacionalistas vascos de no haber acudido a la reunión de Donostia. Esta conducta fue calificada por el líder socialista como un grave error político, ya que de haber suscrito el pacto como los catalanes, los vascos habrían podido disponer tan pronto como ellos de su Estatuto de autonomía. Pero, ¿fueron los nacionalistas vascos invitados al Pacto de Donostia? Por lo que hemos visto, creemos que no. Indalecio Prieto, no obstante, afirma lo contrario: «(...) Cuando en 1930 se les requirió para concertarse con todos los elementos antidinásticos del país vasconavarro a fin de luchar juntos contra la Monarquía, negaron su cooperación...” ${ }^{57}$.

La declaración del Sr. Prieto, hecha en una carta que dirige al presidente de la Diputación de Vizcaya, al socialista Rufino Laiseca, tuvo contestación inmediata por parte de Euzkadi. En un artículo titulado «Comentarios a un Documento de Actualidad" del 24 de septiembre de 1932, el jelkide Manuel Eguileor desmiente las palabras del líder socialista. Según Eguileor, el PNV tuvo requerimientos de esta índole únicamente en dos ocasiones, la primera en 1929 y la segunda en 1930, advenida ya la Dictadura Berenguer. En la primera, dos representantes del PNV se entrevistaron en casa de don Ramón María de Aldasoro con este señor y con un

${ }^{56}$ Euzkadi,7-agosto-1931. «Los secretos del Pacto de San Sebastián». Cuenta Aiguadé que se creó un comité director formado por Alcalá Zamora, Azaña, Casares Quiroga, Prieto, Galarza y él mismo. Se nombró un segundo comité, en el supuesto de que el primero fuera encarcelado: Miguel Maura, Maciá, Mallol y Sánchez Román.

57 José Antonio de AGUIRRE Y LekUBE: Entre la libertad y la revolución. 1930-1935. Editorial Geu. 593 págs. págs. 334-336. Puede verse también en Euzkadi, 23-septiembre-1932.

Carta dirigida a su amigo, también socialista, Rufino Laiseca. 
representante del sector jaimista. Según se les hizo saber «el golpe estaba próximo a darse y corría a cargo de los militares. De los nacionalistas se queria saber solamente si en el momento en que los militares antidictatoriales derrocasen a Primo de Rivera, haciéndose cargo del Poder, estarían dispuestos a ejercer una simple acción civil: la de hacerse cargo de los Ayuntamientos y ayudar al mantenimiento del orden en todos los pueblos del País Vasco en que contaban con fuertes núcleos de opinión. Los dos nacionalistas vascos contestaron claramente que sí, y que para derribar la Dictadura estarian siempre dispuestos. Este plan militar fracasó y no les volvieron a hablar del asunto.

En la segunda ocasión, que es a la que alude el Sr. Prieto, volvieron a estar citados en casa de Aldasoro. Eguileor no señala la fecha, pero dice que fue en 1930, durante la Dictadura Berenguer. El dirigente jelkide refiere que fue una reunión muy nutrida y semipública, puesto que se facilitó una nota oficial a la Prensa con el único acuerdo adoptado por los concurrentes en representación de sus respectivos partidos: republicano, socialista, jaimista, Comunión Nacionalista y Partido Nacionalista Vasco. El acuerdo consistia en que los partidos citados se comprometian a no aceptar cargos en las Corporaciones populares (Ayuntamientos y Diputaciones) mientras los proveyera el Gobierno, como lo había anunciado por Real orden.

Se habló del próximo derrumbamiento de la Monarquía y naturalmente, lo€ nacionalistas vascos manifestaron que «eran republicanos vascos y estaban más hartos que nadie de las monarquias españolas, pero que bueno sería conocer qué les prometía la República española en caso de instauración». Concluye el Sr. Eguileor diciendo que «no hubo más que eso». Que el «Partido Nacionalista Vasco no volvió a ser convocado para ninguna otra reunión ni solicitado para ninguna otra acción antimonárquica».

No parece que el PNV fuera invitado al llamado Pacto de San Sebastián. Pero aunque lo hubiera sido, probablemente no habría aceptado la invitación porque su acentuado derechismo le pedia colaborar en la implantación de un régimen que se estaba destapando con unos caracteres laicos y anticlericales. Su implantación era una amenaza para la religión católica y para el orden social establecido. El nacionalismo vasco estaba todavía en 1930 bajo el control de los nacionalistas de «la vieja guardia», y el primer término del lema JEL, pesaba demasiado como para colaborar en una empresa que a todas luces constituía un peligro para su integrismo religioso. Además, para los dirigentes jelkides, la recuperación de sus libertades históricas no estaba vinculada a un determinado régimen político. La Monarquia se las había arrebatado y la República no se las iba a 
devolver: «(...) República es Francia hace muchos años, ¿y qué libertad concede a nuestros hermanos de raza? $»^{58}$.

Ante el advenimiento de la República, el PNV se muestra con un lenguaje y una conducta en absoluta coherencia con la doctrina sabiniana abrazada en Vergara. En vísperas de las elecciones municipales del 12 de abril del 31, en el mitin celebrado en el Euzkalduna, intervienen los jelkides Manuel Eguileor, Enrique de Orueta, León de Urriza, José Antonio de Aguirre, Alejandro de Gallastegui y Elías Gallastegui. En su intervención casi todos resaltan su negativa a colaborar con otros partidos y el carácter ajeno que para ellos tiene la cuestión. Su conducta y su lenguaje nos recuerdan los mejores días de Sabino. Asi se expresaba Enrique de Orueta:

«(...) Del Ebro para allá, nada, que no es nuestro problema. $Y$ al que diga que el Partido Nacionalista Vasco se une con los monárquicos o con las izquierdas, contestadle que miente, pues va solo, con las banderas desplegadas al triunfo, por JEL, por Sabino y por la Patria Soberana”.

Los dos Gallastegui utilizan el mismo tono y resaltan la misma idea:

«(...) No admitimos componendas ni con los de la derecha ni con los de la izquierda. váyanse monárquicos y republicanos a la orilla opuesta del Ebro...”

¡Al servicio de la Monarquía española, nunca!

¡Al servicio de la República española, nunca!

¡Al servicio de poderes extraños, vengan de donde vinieran, jamás!

¡Sólo al servicio de nuestra Patria!» ${ }^{59}$.

Ante la contienda electoral que llegó a implantar la República en España, los dos conceptos que quizá mejor expresan la conducta de los nacionalistas jelkides son los de indiferencia y escepticismo. Indiferencia en cuanto al régimen y escepticismo en cuanto a las escasas o nulas posibilidades de implantación ${ }^{60}$.

58 Euzkadi. 9-diciembre-1930. «Tendencia a la unión con las izquierdas». Leonardo.

59 Euzkadi. 7-abril-1931. «El gran mitin del Euzkalduna».

60 Eugenio IBARzÁBAL: 50 años de Nacionalismo Vasco 1928-1978. Ediciones Vascas. 392 págs. «Manuel de Irujo», pág. 15: «No esperábamos la llegada de la República, pensábamos que iba a tardar bastante más, que aquello necesitaba madurarse, que sucedería un "interregno" más o menos blando que provocaría manifestaciones y traería la República". puede verse también Euzkadi, 4-febrero-1931, 19 y 22-marzo, 7 y 11-abril-1931. 
Nadie, escribe Joaquín Arrarás, ni los propios republicanos, esperaban un resultado electoral tan aplastante y catastrófico para la Monarquía. «Es ingenuo -había dicho Azaña a un redactor de La Tierra- esperar algo de las elecciones". Ninguna confianza le inspiraba a Largo Caballero el torneo electoral, «juego inútil y sin importancia que únicamente servirá para fortalecer al Trono". «Nadie creía ni esperaba en España que el cambio se realizase -escribe el jefe radical Lerroux-como consecuencia de unas elecciones, y menos de estas elecciones" ${ }^{61}$.

Proclamada la República, el PNV manifiesta una actitud bien distinta de la que había mantenido durante la campaña electoral. Si durante esta contienda le daba lo mismo Monarquía que República, implantada ésta, su actitud cambia notablemente. Existe una notoria inquietud o preocupación en el PNV por exteriorizar su apoyo al nuevo régimen y por demostrar la sinceridad de su nueva actitud. Como prueba de esta sinceridad alude a los decretos de sus autoridades dirigidos a los afiliados y a los acuerdos tomados por los ayuntamientos nacionalistas de colocar la bandera republicana en las Casas Consistoriales, así como a las manifestaciones organizadas en las capitales de provincia a favor de la República ${ }^{62}$.

A partir de 1930 irrumpe con fuerza en la vida política del País Vasco una joven generación de jelkides que conducirá al PNV durante la II República por las sendas de una progresiva «democratización». El carácter reaccionario que exhibe en 1930 irá poco a poco cediendo ante el influjo de esta joven generación. Se convertirá en un partido de masas, impregnado de unas doctrinas católicas modernas que le llevarán a concepciones avanzadas en el terreno social y en el político al descubrimiento del valor cristiano de la democracia ${ }^{63}$.

Esta joven generación integrada por figuras relevantes del nacionalismo jelkide, José Antonio de Aguirre, Leizaola, Irujo, Monzón, Izaurieta, Ira-

\footnotetext{
61 Joaquin Arrarás: Historia de la segunda República Española. Editora Nacional, Madrid, 1970. 4 tomos. Tomo I, págs. 14-15.

62 Euzkadi. 14-mayo-1931. «El partido Nacionalista Vasco arite el Gobierno Republicano». Como prueba de su sinceridad alude a ciertos hechos y una prueba documental. Actitud del PNV en la politica general republicana: «La actitud del Partido Nacionalista Vasco en los momentos actuales es de franca y cordial adhesión al Gobierno de la segunda República española, del que reclama y espera el reconocimiento de la personalidad natural y jurídica del País Vasco con el derecho a constituirse y gobernarse por si mismo, vinculado mediante la forma republicana federal, con las mismas personalidades peninsulares.

63 Javier TuSELl Gómez: Historia de la Democracia cristiana española. / Nacionalismo Vasco y Catalán. Los Solidarios, la Guerra Civil. Madrid, Impr. Talleres Gráficos Montaña, páginas 13-14.
} 
zusta... ejercerá una notable influencia en la comunidad nacionalista vasca durante este período. Todos ellos ejercieron cargos de responsabilidad en el partido o como diputados en el Parlamento español. La dirección del nacionalismo jelkide, dada su relevancia politica, pasa, en cierto modo, a estar en sus manos, lo cual facilita su evolución hacia formas más democráticas. El mismo Aguirre aplicó la doctrina social de las encíclicas papales en su propia empresa ${ }^{64}$.

\section{LAS ELECCIONES MUNICIPALES DE ABRIL DE 1931}

Como ya se ha dicho, el PNV se presentó sólo a estos comicios. ANV, en cambio, entró a formar parte del bloque antimonárquico con republicanos y socialistas. Se trataba de unas elecciones de carácter administrativo. Su finalidad era la de constituir los Ayuntamientos. Estos quedaron constituidos, unos, por la aplicación del artículo 29 de la vigente ley electoral de 1907, y otros, por la elección popular que se llevó a cabo el domingo día 12 de abril de 1931, elección cuyo resultado implantó, inesperadamente, la República en España.

Casi la mitad de los Ayuntamientos vascos quedó constituida por la aplicación del artículo 29. Según este artículo, quedaban automáticamente elegidos, sin necesidad de presentarse a la elección, aquellos candidatos que en un distrito no llegasen a superar el número de los que la ley autorizaba. Según los datos que nos ofrece el Euzkadi de 25 de abril de 1933, en Vizcaya se eligieron 53 ayuntamientos por la aplicación de este artículo y 42 en Guipúzcoa. En Alava, 29 y en Navarra, 149.

El diario Euzkadi del 25 de abril de 1933 publicó el resultado de la proclamación de estos Ayuntamientos en las provincias de Guipúzcoa y

${ }^{64}$ A.S. Bilbao, legajo, $n^{\circ} 10$. Carta de F. Javier de Landáburu a José Antonio de Aguirre pidiéndole que envie al compatriota Guillermo de Ascorreta una exposición detallada sobre "el mecanismo de sus magníficas reformas sociales» llevadas a la práctica en su factoría "Chocolates Bilbainos". 12-nov-1932. A.S. Bilbao, legajo $n^{\circ} 10$. Carta dirigida a Antonio Villanueva: «(...) He recibido su carta y veo que mi buen amigo D. Onaindia sigue leyendo por esos mítines los artículos del Reglamento de trabajo de nuestra fábrica. Es cosa que no me gusta se haga en público como varias veces se lo he advertido, porque entiendo que no debiera ser el caso tan extraño que hubiera que sacarlo a luz pública como modelo. (...) Aún espero introducir otras mejoras como la pensión de vejez y la casa propia. Son todas estas cosas obligación de quien se precie de seguir las doctrinas sociales cristianas y acabar de una vez con la farsa que tanto nos ha perjudicado"...6-febrero-1932. 
Vizcaya. El Gobierno social-azañista habia disuelto por decreto los Ayuntamientos que habian sido constituidos por el artículo 29; según monárquicos y nacionalistas, para republicanizar los ayuntamientos rurales. La nueva elección fue en abril de 1933. Con la finalidad de comparar los resultados del 31 con los del 33, el diario Euzkadi los publicó en la citada fecha.

\section{Proclamados por el artículo 29 en Guipúzcoa el día 5-abril-1931}

\begin{tabular}{|c|c|}
\hline Independientes & 100 \\
\hline Tradicionalistas y jaimistas ................... & 71 \\
\hline 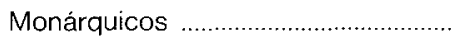 & 94 \\
\hline Nacionalistas & 55 \\
\hline 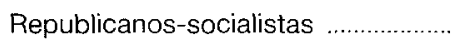 & 5 \\
\hline Sin filiación. ... & 8 \\
\hline TOTAL de concejales & 333 \\
\hline
\end{tabular}

\section{En Vizcaya por el artículo 29 día 5 de abril de 1931}

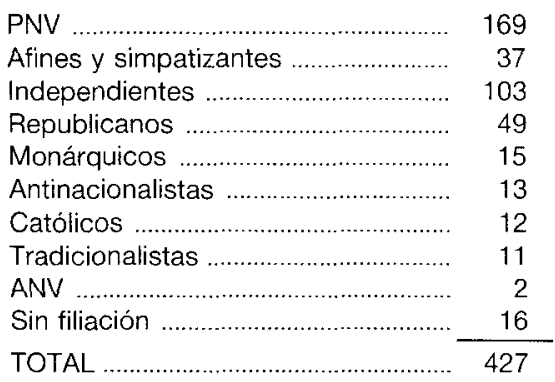

Elegidos en abril de 1933

\begin{tabular}{|c|c|}
\hline Independientes & 57 \\
\hline Tradicionalistas y jaimistas .................. & 55 \\
\hline Agrarios & 10 \\
\hline 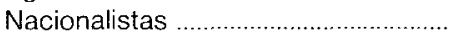 & 180 \\
\hline (n) & 15 \\
\hline ANV & 2 \\
\hline Socialistas ................ & 1 \\
\hline TTAL & 320 \\
\hline
\end{tabular}

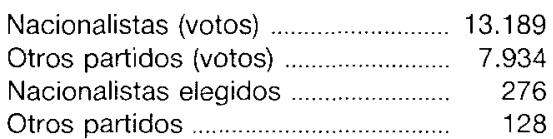

Los Ayuntamientos constituidos por el artículo 29 correspondían fundamentalmente a núcleos rurales de escasa importancia. En estos municipios, muy impermeables a la penetración de los ideales liberales y laicos de la República, el predominio, como se observa, corresponde a monárquicos, tradicionalistas y nacionalistas. En Vizcaya la hegemonía corresponde al PNV. En Guipúzcoa, en cambio, son los monárquicos y los tradicionalistas los elementos predominantes. Hay que destacar el enorme crecimiento experimentado por el PNV en las elecciones de 1933 para cubrir esos mismos puestos. 


\section{Elección popular del 12 de abril de 1931 en Guipúzcoa}

El diario Euzkadi nos ofrece datos sobre 42 pueblos, entre los que figuran los más importantes. Con estos datos hemos elaborado el siguiente cuadro:

\begin{tabular}{|c|c|c|}
\hline & & Porcentaje \\
\hline IZQUIERDAS (Republicanos-socialistas) & 84 & 19,32 \\
\hline DEREChas (Monárquicos, tradicionalistas de las tres ramas, católicos) .... & 204 & 46,89 \\
\hline NACIONALISTAS & 97 & 22,29 \\
\hline INDEPENDIENTES & 32 & 7,35 \\
\hline Otros (demócratas, liberales, apolíticos, Solidaridad Obrera, Pop. Adm.) & 18 & 4,13 \\
\hline TOTAL & 435 & 99,97 \\
\hline
\end{tabular}

La primera fuerza política de Guipúzcoa la constituyen monárquicos y tradicionalistas. La segunda fuerza la constituyen los nacionalistas y en tercer lugar quedan los republicanos y socialistas. Entre las derechas y los nacionalistas casi llegan al 70 por 100. Las izquierdas sólo triunfaron en la capital y en algunas ciudades industriales como Eibar, Irún y Mondragón.

\section{Elección popular del 12 de abril de 1931 en Vizcaya}

(Datos sobre 17 ciudades con una población superior a 6.000 habitantes)

\begin{tabular}{|c|c|c|}
\hline & & Porcentaje \\
\hline Republicanos ............................ & 47 & 14,82 \\
\hline Socialistas & 70 & 22,08 \\
\hline ANV $\ldots \ldots \ldots$ & 26 & 8,20 \\
\hline PNV & 86 & 27,12 \\
\hline Monárquicos & 76 & 23,97 \\
\hline PCE & 7 & 2,20 \\
\hline Independientes & 4 & 1,26 \\
\hline Jaimistas & 1 & 0,31 \\
\hline 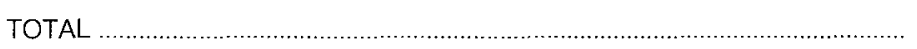 & 317 & 99,96 \\
\hline
\end{tabular}

Fuente: Euzkadi, 14 de abril de 1931 y José LuIS DE LA GRANJA, op. cit., pág. 112. 
El reparto de los concejales en la Vizcaya industrial y urbana corresponde a las tres fuerzas mayoritarias: Bloque antimonárquico, PNV y monárquicos. El Bloque triunfa en Bilbao y en la margen izquierda de la ría, donde se encuentra la industria siderúrgica y la mineria del hierro: Baracaldo, Sestao, Portugalete, Ortuella, Santurce y San Salvador del Valle. Los nacionalistas vascos en algunos pueblos importantes de la costa: Guecho, Bermeo, y en algunos del interior: Valmaseda, Galdácano y Munguia. Los monárquicos en Basauri, Durango y Guernica.

En la Vizcaya rural se eligieron 318 concejales que se repartieron entre cuatro fuerzas políticas: 127 monárquicos $(40 \%)$, 83 nacionalistas $(26 \%)$, 47 independientes (15\%) y 32 del Bloque $(10 \%)$. Como se ve, claro predominio de las derechas monárquicas y los nacionalistas sobre las fuerzas del Bloque. En Navarra triunfaron las candidaturas monárquico-tradicionalistas sobre las antimonárquicas y las nacionalistas. En Alava ocurrió prácticamente lo mismo. En ambas los nacionalistas vascos fueron muy poco votados. 